\title{
PENGARUH KUALITAS PRODUK, HARGA DAN KUALITAS LAYANAN TERHADAP KEPUTUSAN PEMBELIAN JANJI JIWA COFFEE CITRA RAYA
}

\author{
Amo Sugiharto $^{1 *}$, Mohamad Fajar Darmawan ${ }^{2}$ \\ ${ }^{1,2}$ Universitas Esa Unggul \\ *Email: amo.sugiharto@ esaunggul.ac.id
}

\begin{abstract}
Abstrak
Tujuan penelitian ini adalah untuk mengetahui pengaruh kualitas produk, harga dan kualitas layanan terhadap keputusan pembelian janji Jiwa Coffee Citra Raya. Penelitian ini menggunakan metode kuantitatif. Penelitian ini menggunakan jenis penelitian assosiatif kausal. Responden dalam penelitian ini berjumlah 120 orang pengambilan sampel pada penelitian ini menggunakan metode non probability sampling. Metode analisis data dalam penelitian ini adalah menggunakan uji validitas, uji realibilitas, dan uji t. Berdasarkan hasil penelitian dapat ditarik beberapa kesimpulan sebagai berikut: 1) Kualitas produk memiliki pengaruh yang signifikan terhadap keputusan pembelian. Hal ini berarti semakin melakukan inovasi produk yang memberikan keunggulan produk tersebut; 2) Harga memiliki pengaruh yang signifikan terhadap keputusan pembelian Janji Jiwa Coffee di Citra Raya; dan 3) Kualitas Layanan memiliki pengaruh yang signifikan terhadap keputusan pembelian Janji Jiwa Coffee di Citra Raya.
\end{abstract}

Kata Kunci: Kualitas Produk, Harga, Kualitas Layanan, Keputusan Pembelian.

\section{Abstract}

The purpose of this study was to determine the effect of product quality, price and service quality on the purchasing decision of Jiwa Coffee Citra Raya. This study uses quantitative methods. This research uses causal associative research. Respondents in this study amounted to 120 people. Sampling in this study used a non-probability sampling method. The method of data analysis in this study is to use the validity test, reliability test, and t test. Based on the results of the analysis and discussion that have been described previously, several conclusions can be drawn from the overall research results, namely: 1) Product quality has a significant influence on purchasing decisions. This means more product innovations that give the product superiority; 2) Price has a significant influence on the purchasing decision of Promise Jiwa Coffee in Citra Raya; and 3) Service quality has a significant influence on the purchasing decision of the Promise Jiwa Coffee in Citra Raya.

Keywords: Product Quality, Price, Service Quality, Purchase Decision.

\section{A. PENDAHULUAN}

Kedai kopi atau coffee shop saat ini menjadi minat bisnis yang menjamin, dari sekian banyak bisnis kuliner. Seiring perkembangan konsumsi kopi di Indonesia yang semakin meningkat menciptakan suatu persaingan yang semakin pesat, khususnya di kalangan remaja. Bisnis coffee shop menjadi salah satu bisnis yang diminati oleh masyarakat dalam beberapa tahun ini, termasuk di Citra Raya Tangerang. Para Produsen atau pemilik coffee shop baik yang memiliki merek sendiri maupun franchise dituntut untuk memberikan kualitas produk, harga, dan layanan agar mampu menarik konsumen untuk kembali membeli produk yang dipasarkan. Adapun beberapa coffee shop yang berada di Citra Raya Tangerang dengan merek sendiri 
kurang begitu peminat, namun beda halnya dengan franchise yang begitu banyak peminat dalam melakukan keputusan pembelian. Maka dari itu dengan memperkuat tuntutan tersebut diharapkan pemilik coffee shop mampu bersaing memperebutkan pelanggan dengan sajian minuman kopi berkualitas, harga terjangkau dan konsep gerai lebih sederhana (Albina Anim, 2020).

Kopi Janji Jiwa Coffee Citra Raya telah melakukan kerjasama dengan Grab/Gojek saat ini, baik Janji Jiwa Coffee di Citra Raya maupun diluar Citra Raya Tangerang. Dengan bekerjasama pada mitra Gojek/Grab dapat memudahkan produsen dalam penjualan, seperti memberikan diskon semasa pandemic yang membuat konsumen mudah dalam melakukan pembelian serta menarik karena adanya diskon dalam pembelian, dengan memberikan banyak diskon setiap bulannya, dapat mempermudah pembelian dengan intensitas pembeli yang antusias. Mengingat begitu besarnya penikmat kopi di Indonesia, maka penting bagi perusahaan coffee shop untuk melakukan peningkatan kualitas produk kopi yang dipasarkan. Salah satu sistem periklanan yang digunakan perusahaan untuk mempromosikan produknya yaitu harga. Dimana harga digunakan sebagai alat untuk menunjang penjualan, namun harga juga digunakan untuk membangun citra suatu produk. Secara historis, harga menjadi faktor penting yang mempengaruhi pilihan pembelian. Seperti menurut penelitian (Samosir dan Prayoga, 2015), dapat ditarik simpulan bahwasanya harga mempunyai pengaruh yang positif terhadap keputusan pembelian konsumen.

Pada penelitian ini, peneliti melakukan pra-survey atau penelitian awal dengan membagikan kuesioner yang telah dibuat dan disebarkan kepada 32 responden yang telah membeli produk di Kopi Janji Jiwa Coffee di Citra Raya, Dari hasil kuesioner awal yang telah disebarkan kepada responden didapatkan hasil bahwa pada variabel harga, 67 persen responden menilai harga produk Janji Jiwa Coffee dapat di jangkau oleh semua konsumen, 73 persen responden menilai produk Kopi Janji Jiwa Coffee Citra Raya sesuai keinginan konsumen. 76 persen responden menilai fasilitas yang ada di Kopi Janji Jiwa Coffee Citra Raya memadai atau konsumen dapat menikmati kopi di tempat. 69 persen responden menilai akan membeli Kopi Janji Jiwa kembali. Berikut hasil pra-survey kepada 32 responen yang telah membeli Kopi Janji Jiwa Citra Raya Dari keseluruhan responden yang menjawab melalui kuesioner, dapat disimpulkan bahwa kualitas produk, harga dan kualitas layanan faktor penting dalam melakukan keputusan pembelian. Penelitian ini bertujuan untuk (1). Mengetahui kualitas layanan terhadap keputusan pembelian Janji Jiwa Coffee Citra Raya, (2). Mengetahui kualitas produk terhadap keputusan pembelian Janji Jiwa Coffee Citra Raya, (3). Mengetahui harga terhadap keputusan pembelian Janji Jiwa Coffee Citra Raya. Hasil penelitian diharapkan dapat menambah wawasan mengenai pengaruh kualitas produk, harga dan kualitas layanan terhadap keputusan pembelian serta bermanfaat pada penelitian selanjutnya, selain itu hasil penelitian ini diharapkan menjadi sebuah evaluasi bagi perusahaan dalam menentukan kualitas produk, harga dan kualitas layanan sehingga dapat meningkatkan keputusan pembelian kembali bagi konsumen terhadap perusahaan.

\section{B. TINJAUAN PUSTAKA}

\section{Kualitas Produk}

Menurut (Kotler, P. dan Keller, 2012) menyatakan bahwa kualitas produk merupakan kemampuan suatu produk untuk melaksanakan fungsinya, meliputi daya tahan, keandalan, ketepatan, kemudahan operasi dan perbaikan serta atribut bernilai lainnya. Kotler dan Keller dalam (Rondonuwu, 2013) menyatakan sekarang konsumen lebih terdidik dan terinformasi dari pada dahulu, dan mereka memiliki alat untuk menguji klaim-klaim perusahaan dan mencari alternatif-alternatif unggul. Dari pendapat diatas dapat disimpulkan bahwa kualitas produk adalah sejauh mana ataupun seberapa besar tingkat kelayakan suatu produk atau jasa itu digunakan yang dapat memuaskan konsumen dan mengadakan perbaikan setidaknya ada 
yang kurang di sebuah inovasi suatu produk. Sedangkan menurut (Kotler Philip dan Amstrong, 2012) mendefinisikan : Product quality : The characteristics of a product or service that bear on its ability to satisfy stated or implied customer needs".

Menurut Tjiptono dan Chandra dalam (Arianty, 2015) Kualitas produk memiliki indikator yang dapat digunakan untuk menganalisis karakteristik dari suatu produk dengan delapan indikator sebagai berikut : (1). Kinerja (Performance) (2). Fitur atau ciri-ciri tambahan (Features) yaitu karaktersitik sekunder atau pelengkap, (3). Reliabilitas (Reliability) (4). Kesesuaian dengan spesifikasi (Confermance to Specifications) (5). Daya tahan (Durability) yaitu berkaitan dengan berapa lama produk tersebut dapat digunakan. Dimensi ini mencakup umur teknis maupun umur ekonomis, (6). Serviceability (7). Estetika (Esthetics) (8). Kualitas yang dipersepsikan (Perceived Quality).

\section{Harga}

Menurut (Buchari Alma, 2011) harga adalah satuan moneter atau ukuran lainnya (termasuk barang dan jasa lainnya) yang ditukarkan agar memperoleh hak kepemilikan atau penggunaan suatu barang dan jasa sehingga menimbulkan kepuasan konsumen. Menurut (Assauri, 2014), harga merupakan satu-satunya unsur marketing mix yang menghasilkan penerimaan penjualan, sedangkan unsur lainnya hanya unsur biaya saja. Sedangkan menurut (P. dan G. A. Kotler, 2010) Harga merupakan sejumlah uang yang dibebankan atas suatu produk atau jasa atau jumlah dari nilai yang ditukar konsumen atas manfaat-manfaat karena memiliki atau menggunakan produk atau jasa tersebut. Harga dapat diartikan sebagai jumlah uang (satuan moneter) dan/atau aspek lain (non-moneter) yang mengandung utilitas/kegunaan tertentu yang diperlukan untuk mendapatkan suatu produk. (Fandy Tjiptono, 2008) Harga adalah jumlah uang (ditambah beberapa barang kalau mungkin) yang dibutuhkan untuk mendapatkan sejumlah kombinasi dari barang beserta pelayanannya. Menurut Swastha dalam (Rondonuwu, 2013) Harga merupakan bentuk biaya moneter yang dikorbankan oleh konsumen untuk memperoleh, memiliki, memanfaatkan sejumlah kombinasi dari barang beserta pelayanan dari suatu produk.

\section{Kualitas Layanan}

Kualitas layanan didefinisikan menjadi evaluasi pelanggan atas keunggulan atau keistimewaan suatu produk atau layanan secara spesifik terhadap konsumen (A. Parasuraman, Valarie A. Zeithaml, 1988). (Bastos dan Gallego 2008) menunjukan bahwa kualitas layanan merupakan peranan yang penting untuk mendorong pelanggan merasa puas serta loyal pada perusahaan. (Bloemer et al., 1998) Dimana kualitas layanan merupakan suatu proses evaluasi menyeluruh pelanggan tentang kesempatan kinerja layanan. Kualitas pelayanan berkaitan erat menggunakan persepsi pelanggan mengenai mutu suatu bisnis, Semakin baik pelayanan yang akan mensugesti taraf kepuasan yang dirasakan pelanggan sebagai akibatnya bisnis tadi akan dievaluasi semakin bermutu (Michael Christian dan Vincent Nuari, 2014).

Kualitas layanan bisa disimpulkan menjadi suatu manfaat yang bisa dirasakan konsumen dan sifatnya intangible (sunyoto, 2012). Kualitas layanan sendiri dipengaruhi 5 dimensi kualitas layanan yaitu: (a) Dimensi reliability/kehandalan yang mencakup kemampuan perusahaan untuk menaruh pelayanan terbaik pada konsumennya, (b) Dimensi responsiveness/ tanggapan yang mencakup hasrat perusahaan untuk menaruh pelayanan yang cepat dan tanggap, (c) Dimensi assurance/kepastian yang mencakup kemampuan perusahaan untuk membangkitkan rasa kepercayaan pelanggan tentang produknya, (d) Dimensi emphaty/ikut merasakan yang mencakup rasa kepedulian dan perhatian secara eksklusif yang diberikan dalam pelanggan, (e) Dimensi tangibles/ penampilan fisik (Business dan Surabaya, 2013). 


\section{Keputusan Pembelian}

Keputusan pembelian adalah suatu tindakan konsumen dalam usaha untuk memenuhi kebutuhannya dalam mengkonsumsi suatu produk yang diikuti oleh kepuasan yang dirasakan oleh konsumen tersebut (Kotler dan Amstrong, 2001). (Kotler, Philip dan Armstrong, 2008) menyatakan bahwa "Keputusan pembelian adalah keputusan pembeli tentang merek mana yang dibeli." Dalam keputusan pembelian, ada dua faktor yang muncul antara niat untuk membeli dan keputusan pembelian. Menurut Kotler dan Amstrong dalam (Denny Kristian dan Rita Widayanti, 2016) Terdapat lima tahap yang dilalui konsumen dalam proses pengambilan keputusan pembelian, antara lain : (a). Pengenalan kebutuhan Tahap pertama proses kebutuhan pembeli, (b). Pencarian informasi Tahap proses keputusan pembelian dimana konsumen ingin mencari informasi lebih banyak dalam suatu produk (c). Evaluasi alternatif Tahap proses keputusan pembelian dimana konsumen menggunakan informasi untuk mengevaluasi beberapa merek pilihan, (d). Keputusan pembelian keputusan pembeli tentang merek apa yang ingin dibeli, (e). Perilaku pasca pembelian Tahap proses keputusan pembelian.

Indikator yang digunakan untuk mengukur keputusan pembelian konsumen antara lain : (a). Keputusan terhadap produk yang tersedia, artinya produk apa yang menarik maupun mengesankan dalam penjualan sehingga dapat meningkatkan keputusan pembelian kembali, (b). Keputusan terhadap harga yang tersedia, sangat berpengaruh dalam penjualan, apabila harga tidak sesuai dengan produk maka dapat menghilangkan konsumen, (c). Keputusan terhadap harga yang diberikan, sama halnya harga yang tersedia dalam penjualan, (d). Keputusan terhadap pelayanan yang diberikan berpengaruh terhadap konsumen yang akan membeli suatu produk (Tjia dan Kadafi, 2017).

\section{METODE}

Penelitian ini menggunakan metode kuantitatif. Penelitian ini menggunakan jenis penelitian assosiatif kausal yang menjelaskan bahwa variable independen (X) mempengaruhi variable dependen $(\mathrm{Y})$. Variabel dalam penelitian ini antara lain kualitas produk ( $\left.\mathrm{x}_{1}\right)$, harga $\left(\mathrm{x}_{2}\right)$, kualitas layanan $\left(\mathrm{x}_{3}\right)$ dan Keputusan pembelian (Y) .Penelitian menggunakan data kuantitatif yang diperoleh dari responden melalui kuesioner untuk menjawab pertanyaan penelitian mengenai kualitas produk $\left(\mathrm{x}_{1}\right)$, harga $\left(\mathrm{x}_{2}\right)$, kualitas layanan $\left(\mathrm{x}_{3}\right)$ dan Keputusan pembelian (Y). Responden dalam penelitian ini berjumlah 120 orang, pengambilan sampel pada penelitian ini menggunakan metode non probability sampling dengan kriteria sebagai berikut: 1) Usia minimal 17 tahun; dan 2) Merupakan pembeli Kopi Janji Jiwa Coffee di Citra Raya Tangerang. Metode analisis data dalam penelitian ini adalah menggunakan uji validitas, uji realibilitas, dan uji t.

\section{HASIL DAN PEMBAHASAN}

\section{Analisis Deskriptif Penelitian}

Analisis deskriptif ini dilakukan untuk mendapatkan gambaran deskriptif mengenai responden penelitian ini, khususnya mengenai variabel-variabel penelitian yang digunakan. Analisis ini dilakukan dengan menggunakan teknik analisis indeks, untuk menggambarkan persepsi responden atas item-item pernyataan yang diajukan. Karakteristik responden dalam penelitian ini disajikan dalam tabel berikut:

Tabel 1. Responden Penelitian

\begin{tabular}{|c|c|c|c|}
\hline \multicolumn{2}{|c|}{ Keterangan } & Jumlah & Persentase \\
\hline \multirow{2}{*}{ Jenis Kelamin } & Laki-Laki & 88 & $72,8 \%$ \\
\cline { 2 - 4 } & Perempuan & 32 & $27,2 \%$ \\
\hline \multirow{3}{*}{ Usia } & $17-21$ tahun & 24 & $19,8 \%$ \\
\cline { 2 - 4 } & $22-25$ tahun & 55 & $45,6 \%$ \\
\cline { 2 - 4 } & $>36$ tahun & 41 & $34,6 \%$ \\
\hline
\end{tabular}


ARTIKEL

\begin{tabular}{|c|c|c|c|}
\hline \multirow{3}{*}{$\begin{array}{c}\text { Pengeluaran } \\
\text { Perbulan }\end{array}$} & 500.000 & 21 & $17,3 \%$ \\
\cline { 2 - 4 } & $500.000-1.500 .000$ & 54 & $45,1 \%$ \\
\cline { 2 - 4 } & $>1.500 .000$ & 45 & $37,6 \%$ \\
\hline \multirow{2}{*}{ Domisili } & Tangerang & 117 & 98,1 \\
\cline { 2 - 4 } & Luar Cikupa & 3 & $1,9 \%$ \\
\hline
\end{tabular}

Sumber: Data Diolah

Berdasarkan table 1 diatas, pelanggan Janji Jiwa Coffee Citra Raya lebih dominan yang berjenis kelamin laki-laki dengan presentase sebesar $72,8 \%$ dengan jumlah responden sebanyak 88 orang. Sehingga dapat disimpulkan bahwa seorang laki-laki memiliki minat yang tinggi dalam pembelian Janji Jiwa Coffee Citra Raya. Selanjutnya, pelanggan Janji Jiwa Coffee Citra Raya lebih dominan berusia 22-25 tahun dengan presentase 45,6\% dengan jumlah responden 55 orang. Dengan hasil yang ada maka dapat disimpulkan rata-rata pelanggan Janji Jiwa Coffee Citra Raya memiliki usia yang bisa dikatakan pelanggan yang sudah bekerja maupun yang belum bekerja dalam menentukan pilihan kopi mana yang menurut mereka murah tetapi rasa yang tidak murahan.

Dari segi pengeluaran perbulan, pelanggan Janji Jiwa Coffee lebih dominan pengeluaran 500.000-1.500.000 perbulan dengan jumlah 54 responden dan presentase $45,1 \%$. Maka berdasarkan data yang ada dapat disimpulkan bahwa pelanggan Janji Jiwa Coffee dalam melakukan pembelian kopi tidak begitu banyak mengeluarkan biaya setiap bulannya. Selanjutnya, pelanggan Janji Jiwa Coffee Citra Raya lebih dominan responden yang berdomisili di Tangerang yaitu sebanyak 117 responden dengan presentase 98,1\% sehingga berdasarkan data yang ada dapat disimpulkan bahwa pelanggan Janji Jiwa Coffee Citra Raya berdomisili di Tangerang sehingga mempermudah untuk melakukan penelitian, Adapun sisanya $1,9 \%$ pernah membeli Janji Jiwa Coffee di Citra Raya atau hanya visit karena urusan pribadi mereka.

\section{Uji Validitas}

Uji validitas digunakan untuk mengukur sah atau valid tidaknya suatu kuesioner penelitian. Dari hasil uji validitas yang telah di uji terhadap 30 responden pada Lampiran 6, bahwa seluruh pernyataan atau sebanyak 24 pernyataan valid. Hal tersebut dikarenakan hasil dari $r$ hitung setiap variabel $>0,361$ atau dapat dikatakan $r$ hitung $>r$ tabel. Sehingga dapat disimpulkan bahwa setiap butir pernyataan layak digunakan dan dapat mengukur indikator dan variabel dalam penelitian ini.

\section{Uji Reliabilitas}

Uji reliabilitas digunakan untuk mengukur suatu kuesioner penelitian yang merupakan indikator dari variabel. Hasil uji reliabilitas dinyatakan cukup reliabel jika Cronbach Alpha 0,41 - 0,60. Jika Cronbach Alpha 0,61 - 0,80 maka instrumen atau kuesioner dinyatakan reliabel, dan jika nilai Cronbach Alpha > 0,80 maka instrumen sangat reliabel. Hasil uji reliabilitas pada Lampiran 6 terhadap 30 responden dalam penelitian ini yaitu sebesar 0,793 artinya bahwa seluruh pernyataan dalam penelitian ini dinyatakan reliabel karena hasil Cronbach Alpha menunjukkan angka 0,793.

\section{Uji t}

Uji t digunakan untuk menguji pengaruh secara parsial atau sendiri-sendiri atau individu, variabel independen mempengaruhi variabel dependen atau tidak. Dengan hasil sebagai berikut: 
ARTIKEL

Tabel 2. Hasil Uji t

\begin{tabular}{|c|c|c|c|c|c|c|}
\hline \multirow{2}{*}{ No. } & \multirow{2}{*}{ Model } & \multicolumn{2}{|c|}{$\begin{array}{c}\text { Unstandardized } \\
\text { Coefficients }\end{array}$} & $\begin{array}{c}\text { Standardized } \\
\text { Coefficients }\end{array}$ & \multirow{2}{*}{$\mathbf{t}$} & \multirow{2}{*}{ Sig. } \\
\cline { 3 - 5 } & & $\mathbf{B}$ & Std. Error & Beta & & \\
\hline 1 & (Constant) & 0,720 & 0,797 & & 0,903 & 0,368 \\
\hline 2 & Kualitas Produk & 0,190 & 0,033 & 0,448 & 5,734 & 0,001 \\
\hline 3 & Harga & 0,200 & 0,063 & 0,255 & 3,166 & 0,002 \\
\hline 4 & Kualitas Layanan & 0,205 & 0,054 & 0,250 & 3,818 & 0,001 \\
\hline
\end{tabular}

Sumber: Data Diolah

\section{Uji Parsial Kualitas Produk Terhadap Keputusan Pembelian}

Untuk mengukur pengaruh parsial variabel Kualitas Produk Terhadap Keputusan Pembelian, maka hipotesis yang digunakan sebagai berikut :

$\mathrm{H}_{0}: \beta_{1}=0$ (artinya variabel Kualitas Produk tidak mempunyai pengaruh signifikan terhadap variabel keputusan pembelian)

$\mathrm{H}_{\mathrm{a}}: \beta_{1} \neq 0$ (artinya variabel Kualitas produk mempunyai pengaruh signifikan terhadap variabel keputusan pembelian)

Berdasarkan tabel 2 di atas, diperoleh $\alpha=$ dengan nilai signifikan $0,001<0,05$ atau $t_{\text {hitung }}=5,734>t_{\text {tabel }}$ 1,980. Maka $\mathrm{H}_{\mathrm{a}}$ diterima dan $\mathrm{H}_{0}$ ditolak dengan tingkat signifikansi $5 \%$ sehingga kesimpulannya secara parsial variabel kualitas produk mempunyai pengaruh signifikan terhadap keputusan pembelian.

\section{Uji Parsial Harga Terhadap Keputusan Pembelian}

Untuk mengukur pengaruh parsial variabel Harga Terhadap Keputusan Pembelian, maka hipotesis yang digunakan sebagai berikut :

$\mathrm{H}_{0}: \beta_{1}=0$ (artinya variabel Harga tidak mempunyai pengaruh signifikan terhadap variabel keputusan pembelian)

$\mathrm{H}_{\mathrm{a}}: \beta_{1} \neq 0$ (artinya variabel Harga mempunyai pengaruh signifikan terhadap variabel keputusan pembelian)

Berdasarkan tabel 5.11 di atas, diperoleh $\alpha=$ dengan nilai signifikan 0,002<0,05 atau $t_{\text {hitung }}=3,166>t_{\text {tabel }} 1,980$. Maka $\mathrm{H}_{\mathrm{a}}$ diterima dan $\mathrm{H}_{0}$ ditolak dengan tingkat signifikansi $5 \%$ sehingga kesimpulannya secara parsial variabel harga mempunyai pengaruh signifikan terhadap keputusan pembelian.

\section{Uji Parsial Kualitas Layanan Terhadap Keputusan Pembelian}

Untuk mengukur pengaruh parsial variabel Kualitas layanan Terhadap Keputusan Pembelian, maka hipotesis yang digunakan sebagai berikut :

$\mathrm{H}_{0}: \beta_{1}=0$ (artinya variabel Kualitas layanan tidak mempunyai pengaruh signifikan terhadap variabel keputusan pembelian)

$\mathrm{H}_{\mathrm{a}}: \beta_{1} \neq 0$ (artinya variabel Kualitas layanan mempunyai pengaruh signifikan terhadap variabel keputusan pembelian)

Berdasarkan tabel 5.11 di atas, diperoleh $\alpha=$ dengan nilai signifikan $0,001<0,05$ atau $t_{\text {hitung }}=3,818>t_{\text {tabel }} 1,980$. Maka $\mathrm{H}_{\mathrm{a}}$ diterima dan $\mathrm{H}_{0}$ ditolak dengan tingkat signifikansi $5 \%$ sehingga kesimpulannya secara parsial variabel Kualitas layanan mempunyai pengaruh signifikan terhadap keputusan pembelian.

\section{Pembahasan}

Hasil Uji yang telah dilakukan menunjukan bahwa Kualitas Produk pada Janji Jiwa Coffee ini memiliki berbagai macam ukuran disertai rasa kopi yang enak atau sesuai dengan harga yang ditawarkan kepada pelanggan. Artinya mempertahankan cita rasa produk yang 
sudah ada kemudian mengembangkan suatu produk untuk jangka yang Panjang akan berimplikasi pada manfaat yang akan didapat konsumen. Kesimpulannya secara keseluruhan, variabel Kualitas Produk memiliki pengaruh signifikan terhadap keputusan pembelian Janji Jiwa Coffee di Citra Raya. Hal ini sejalan dengan penelitian yang pernah dilakukan oleh (Rumaladewi dan Taun, 2019) yang berjudul "Pengaruh Kualitas Produk, Brand Image, dan Penggunaan Jasa Endorsement Terhadap Keputusan Pembelian perhiasan perak di Sunaka Jewelry Celuk" menyatakan bahwa kualitas produk berpengaruh signifikan terhadap keputusan pembelian. Begitupun sejalan dengan penelitian yang pernah dilakukan oleh (Aditya dan Anik, 2017) yang berjudul "Pengaruh Citra Merek dan Kualitas Produk Terhadap Keputusan Pembelian Samsung Galaxy S7 pada pengunjung Plasa Mrina dan WTC Surabaya" menyatakan bahwa kualitas produk berpengaruh signifikan terhadap keputusan pembelian.

Selanjutnya hasil uji yang telah dilakukan menunjukkan bahwa pada variable Harga memiliki keunggulan terhadap harga yang terjangkau atau lebih murah dari pesaingnya, dengan memberikan harga yang lebih murah disertai diskon tidak akan menghilangkan cita rasa kopi yang mewah pada Janji Jiwa Coffee khususnya di Citra Raya Tangerang. Begitupun hasil ini sejalan dengan penelitian yang pernah dilakukan oleh (Wahyuni dan Pardamean, 2016) yang berjudul "Pengaruh Iklan, Harga Dan Kualitas Layanan Terhadap Keputusan Pembelian Kartu Simpati Di Institute Perbanas" menunjukkan bahwa harga berpengaruh positif terhadap keputusan pembelian.

Selanjutnya hasil uji yang telah dilakukan menunjukkan bahwa pada variabel Kualitas Layanan memiliki faktor yang penting bagi perusahaan. Dengan memberikan tempat yang nyaman, bahasa yang mudah dimengerti oleh konsumen dan bisa mengganti pesanan apabila pesanan tidak sesuai, maka akan membuat konsumen merasa puas atau sesuai dengan keinginannya sehingga dapat meningkatkan keputusan pembelian terhadap Janji Jiwa Coffee Citra Raya (Kotler, 2002). Hal ini sejalan dengan penelitian yang pernah dilakukan oleh (Desy Purwanti dan Martinus, 2013) "Pengaruh Kualitas Produk, Harga, Lokasi, dan Kualitas Layanan Terhadap Keputusan Pembelian Kopitiam Oey Surabaya" menyatakan bahwa Kualitas Layanan berpengaruh positif terhadap keputusan pembelian. Begitupun sejalan dengan penelitian yang pernah dilakukan oleh (Sriyanto dan Utami, 2016) yang berjudul "Pengaruh Kualitas Produk, Citra Merek, dan Kualitas Layana Terhadap Keputusan Pembelian Produk Dadone di Jakarta" kualitas layanan secara parsial memiliki pengaruh signifikan terhadap keputusan pembelian. Dari hasil uji F ini, variabel independent yakni kualitas produk, harga dan kualitas layanan secara simultan atau bersama-sama berpengaruh secara signifikan terhadap variabel dependen yaitu keputusan pembelian kopi janji jiwa Citra Raya.

\section{E. KESIMPULAN}

Berdasarkan hasil analisis dan pembahasan yang telah diuraikan sebelumnya, maka dapat ditarik beberapa kesimpulan dari keseluruhan hasil penelitian yaitu: 1) Kualitas produk memiliki pengaruh yang signifikan terhadap keputusan pembelian; 2) Harga memiliki pengaruh yang signifikan terhadap keputusan pembelian Janji Jiwa Coffee di Citra Raya; dan 3) Kualitas Layanan memiliki pengaruh yang signifikan terhadap keputusan pembelian Janji Jiwa Coffee di Citra Raya. Dengan menjual produk yang berkualitas dengan harga yang sesuai disertai kualitas layanan yang baik, diharapkan mampu meningkatkan loyalitas pelanggan terhadap Janji Jiwa Coffee di Citra Raya.

\section{DAFTAR PUSATAKA}

Aditya dan Anik. (2017). Pengaruh Citra Merek dan Kualitas Produk Terhadap Keputusan Pembelian Samsung Galaxy S7 (Studi Pada Pengunjung Plasa Marina dan WTC Surabaya). 7. 
Akbar, M. F. (2019). Pengaruh Kualitas Produk dan Harga Terhadap Keputusan Pembelian Pada PT Toko Online Mitraindo Tangerang Selatan. 6(2), 237-248.

Albina, A, N. L. P. I. (2020). Pengaruh Promosi dan Kualitas Layanan Terhadap Keputusan Pembelian Kembali (Studi Kasus Pada Start Up Coffee Renon Denpasar). Africa's Potential for the Ecological Intensification of Agriculture, 53(9), 1689-1699.

Arianty, N. (2015). Pengaruh Kualitas Pelayanan Dan Kualitas Produk Terhadap Kepuasan Konsumen Handphone Samsung. Jurnal Ilmiah Manajemen dan Bisnis, 16(2), 68-81.

Assauri, S. (2014). Manajemen Pemasaran. Jakarta: Rajawali Pers.

Bastos, J.A.R., \& G. (2008). Pharmacies customer satisfaction and loyalty: A framework analysis. Retrieved from https: www.uva.es/empresa.

Bloemer et., al. (1998). Customer Loyalty in Extended Service Settings. International Journal od Service Industry Management, 10(3).

Boediono, M., Christian, S., \& Immanuel, D. M. (2018). Pengaruh Kualitas Produk dan Kualitas Layanan Terhadap Keputusan Pembelian Konsumen Sealantwax. Jurnal Manajemen dan Start-Up Bisnis, 3(April), 1-10.

Buchari Alma. (2011). Manajemen Pemasaran dan Pemasaran Jasa. Bandung: Alfabeta.

Business, F. E., \& Surabaya, U. C. (2013). Pengaruh Kualitas Produk dan Kualitas Layanan Terhadap Kepuasan Konsumen King Cake. 1, 50-51.

Denny, K., \& Rita, W. (2016). Kualitas Produk dan Harga Terhadap Keputusan Pembelian Sepeda Motor Honda Pada Mahasiswa Kampus 1 Universitas Kristen Krida Wacana. $16(1)$.

Elida, F. R. T. (2015). Pengaruh Kualitas Pelayanan, Word of Mouth, dan Loyalitas Pelanggan Terhadap Niat Pembelian Kembali Pada Bukalapak.com. Ekonomika dan Manajemen, 20(2), 113-120.

Fandy, T. (2008). Strategi Pemasaran. Yogyakarta: Andi Offset.

Gerung, C. J., Sepang, J., \& Loindong, S. (2017). Effect of Product Quality, Price and Promotion To Decision Purchase Nissan X-Trail Car in Pt. Wahana Wirawan Manado. Jurnal EMBA: Jurnal Riset Ekonomi, Manajemen, Bisnis Dan Akuntansi, 5(2), 22212229.

Ghozali. (2016). Aplikasi Analisis Multivariete Dengan Program IBM SPSS. Semarang: Badan Penerbit Universitas Diponegoro.

Hair, J. et. a. (2010). Multivariate Data Analysis (7th ed). United States: Pearson.

Keller, kotler dan. (2009). Manajemen Pemasaran. Jakarta: Erlangga.

Kodu, S. (2013). Harga, Kualitas Produk dan Kualitas Pelayanan Pengaruhnya Terhadap Keputusan Pembelian Mobil Toyota Avanza. Journal of Polymer Science, Part A: Polymer Chemistry, 45(8), 1432-1445. https://doi.org/10.1002/pola.21914

Kotler, P. dan Keller, K. . (2012). Manajemen Pemasaran Jilid I Edisi ke 12. Jakarta, Erlangga.

Kotler, P. (2002). Manajemen Pemasaran, Edisi Millenium. Jakarta: Prenhallindo.

Luthfia, W. E. (2012). Analisis pengaruh kualitas produk, kualitas layanan, dan harga terhadap keputusan pembelian pada Coffe Shop Kofisyop Tembalang. Analisis Pengaruh Kualitas Produk, Kualitas Layanan, Dan Harga Terhadap Keputusan Pembelian Pada Coffe Shop Kofisyop Tembalang.

Manengal, C. D. (2015). The Effect of Service Quality, Quality Product and Pricing on Purchase Decision. Fakultas Ekonomi dan Bisnis, 3(3), 1254-1264.

Michael, C.,\& Vincent, N. (2014). Pengaruh Kualitas Layanan Terhadap Loyalitas Konsumen Studi Kasus : Belanja Online Bhinneka.com.

Okefinance. (2019). Banten Miliki Potensi Penghasil Kopi Terbaik. https://economy.okezone.com/read/2019/07/24/320/2082863/banten-miliki-potensipenghasil-kopi-terbaik

Purwanti, M. D. (2013). Pengaruh Kualitas Produk, Harga, Lokasi, dan Kualitas Layanan 
Terhadap Keputusan Pembelian Kopitiam Oey Surabaya. 551-562.

Rondonuwu, P. (2013). Kualitas Produk, Harga Dan Kualitas Layanan Pengaruhnya Terhadap Kepuasan Konsumen Pengguna Mobil Nissan March Pada PT. Wahana Wirawan Manado. Jurnal Riset Ekonomi, Manajemen, Bisnis dan Akuntansi, 1(4), 718-728. https://doi.org/10.35794/emba.v1i4.2755

Rumaladewi. (2019). Pengaruh Kualitas Produk, Brand Image dan Penggunaan Jasa Endorsment Terhadap Keputusan Pembelian Perhiasan Perak di Sunaka Jewelry Celuk, Sukawati Gianyar. 4(1), 103-114.

Samosir, C. B. H., \& Prayoga, A. B. (2015). Pengaruh Persepsi Harga dan Promosi terhadap Keputusan Pembelian Konsumen Produk Enervon-C. Jurnal Ilmiah Manajemen dan Bisnis, 1(November), 1-13.

Sangadji dan Sopiah. (2013). Prilaku Konsumen: Pendekatan Praktis Disertai:Himpunan Jurnal Penelitian. Yogyakarta: Penerbit Andi.

Sinambow, S., \& Trang, I. (2015). Pengaruh Harga, Lokasi, Promosi Dan Kualitas Layanan Terhadap Keputusan Pembelian Pada Toko Komputer Game Zona Mega Mall Manando. Jurnal Emba, 3(3), 300-311.

Sriyanto, A., \& Utami, D. A. (2016). Pengaruh Kualitas Produk, Citra Merek dan Kualitas Layanan terhadap Keputusan Pembelian Produk Dadone di Jakarta. Ekonomika aan Manajemen, 5(2), 163-175.

Sugiyono. (2016). Metode Penelitian Kuantitatif, Kualitatif dan R\&D. Bandung: Alfabeta.

Sujarweni, V. W. (2014). Metode Penelitian: Lengkap, Praktis, dan Mudah Dipahami. Yogyakarta: Pustaka Baru Press.

sunyoto. (2012). Manajemen Sumber Daya Manusia. Jakarta: Buku Seru.

Tjia, H. S., \& Kadafi, M. A. (2017). Pengaruh harga kualitas produk dan distribusi terhadap keputusan pembelian. 14(2), 92-97.

Tjiptono, F. (2007). Strategi Pemasaran. Yogyakarta: Andi Ofset.

Wahyuni, S., \& Pardamean, J. (2016). Pengaruh Iklan, Harga Dan Kualitas Layanan Terhadap Keputusan Pembelian Kartu Simpati Di Institute Perbanas. Jurnal Studi Manajemen dan Bisnis, 3(1), 1-18. 